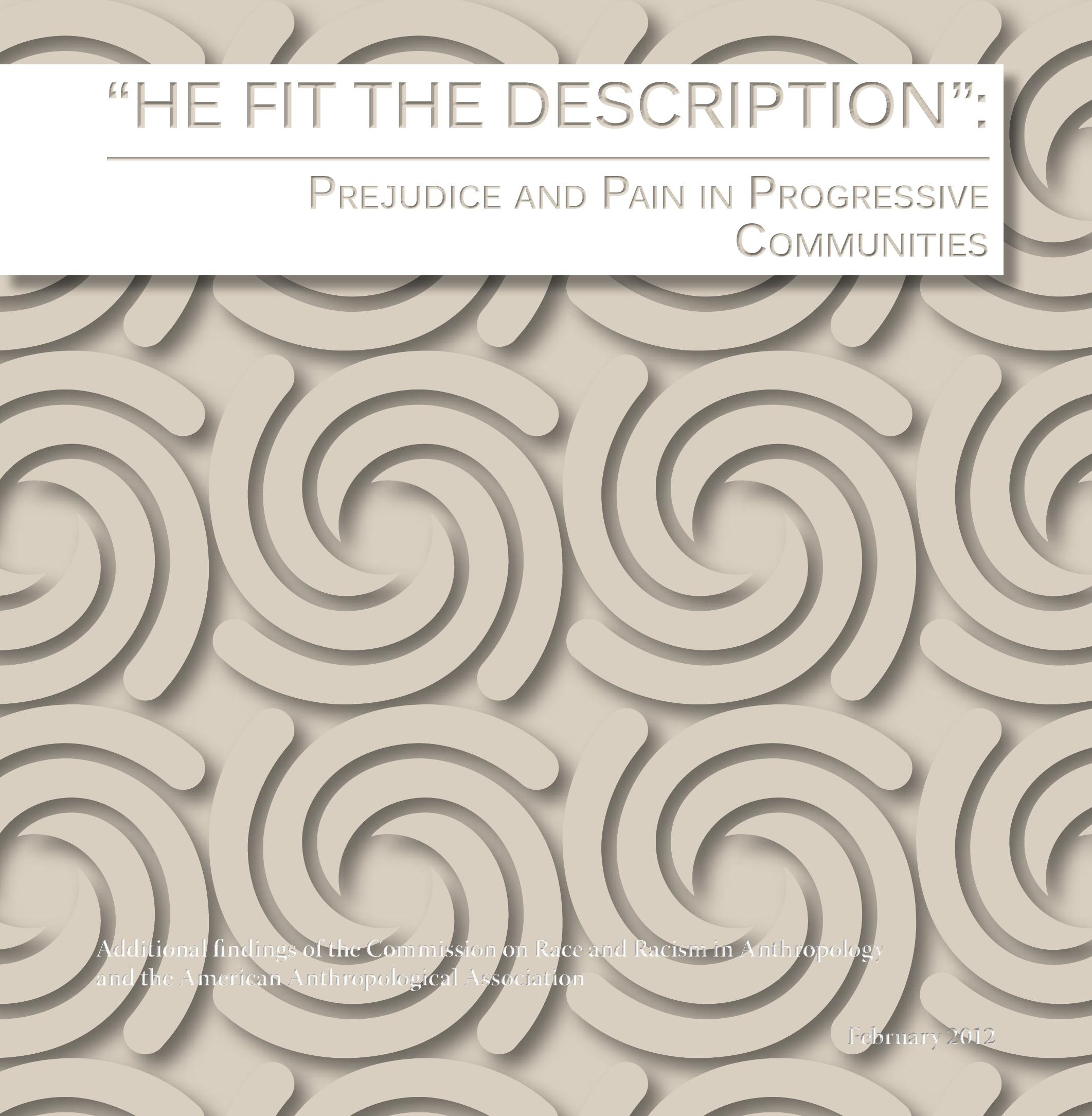




\section{"HE FIT THE DESCRIPTION": Prejudice and Pain in Progressive Communities}

J. Lorand Matory

Duke University

When my son entered pre-kindergarten in the Cambridge Public Schools, he entered smart, capable, and curious. One day, this four-year-old asked the teacher to give him some multiplication problems, and she obliged. $0 \times 0=, 1 \times 1=, 2 \times 2=, \ldots .$. up to $10 \times 10=$. And he got all the answers right. Weeks later, during a parentteacher-student breakfast, he proudly showed us his work. As the teacher rushed past our table, on the way to addressing some other urgent hosting duty, she paused long enough to blurt out, "Oh, those are some math problems Adu asked me to give him, and I was so worried. I was so worried!" Fearing that my son would feel discouraged, I called no attention to her words. As she passed by again, however, I rebounded, "Oh, [teacher's name], this is wonderful work. We are so proud of what Adu has done here! You were saying?" Though I opened a mile-wide door for her to affirm my son's efforts and to encourage this school-appropriate behavior, she instead reaffirmed her worry that he had refused to go out to the playground with the other children until he had finished his math.

On another occasion, she asked the students to string beads in a pattern. Unlike any of the other students, Adu grasped the concept and executed it perfectly. He strung five yellow beads, five black beads, five red beads, and five blue beads, then five yellow, five black, five red, five blue, and so on until he had completed necklace about 17-inches in length. Then the teacher had the children do crayon drawings of the pattern on paper. In time for the parent-teacher conferences, the teacher posted the bead strands and drawings on a cork board, which she showed my wife and me. She explained the project to us: "I wanted to teach the concept of patterns, so I had the students string beads in a pattern and then draw the pattern." She then swiftly concluded, "And Adu just couldn't draw the pattern. He just coooouuuuulllllddddnnnn'tttt draaaaaw the paaaatterrrrrn," as she wagged her head in pity. Admittedly, the drawing was not particularly good. None of the kindergartners had successfully drawn anything that one could call a pattern. But Adu was the only child who had strung beads in anything like a pattern, and the pattern was perfect. Do you think she acknowledged his success? No. 
Amid the omnipresent media cliché that the failings of black parents are the real cause the so-called "racial achievement gap," many parents of black children will recognize this teacher's pattern of response to their children's accomplishments and wonder whether the media have not deliberately ignored a more important, psychological obstacle to black kids' engagement with school. They will also wonder whether our active involvement in our children's education is a welcome as that of other parents.

Most people would rightly regard my son's hard-working, good-willed white female teacher as liberal, and I have no doubt that she cares about her students. Indeed, she reportedly had given $\$ 100,000$ to the single black mother of three students in the school in order to help her buy a house. It is a confusing lesson that some members of hereditarily privileged groups are comfortable with largesse toward their social inferiors, but they can be, at the same time, very uncomfortable with signs of ambition and intellectual superiority among them.

Some experiences offer subtle lessons about race in progressive communities. Some do not. One night in 1980, just a few years after the busing crisis, I was a college student walking through Harvard Square. Two college-aged white men were coming in the opposite direction and, instead of moving to their right so that I could pass on my right, they parted ways around me, and one of them punched me in the stomach. I was completely winded, so I could not shout for help. All I could do was keep walking. There was no help in sight.
In other experiences, you are not sure the issue is racism, but you know the victim and the assailant are both writhing in the bear trap of American race. Every eight or ten months, there is a rash of thefts in Harvard University's William James Hall, where my office was located during 15 of my 18 years on the faculty there. Somebody starts walking into unlocked offices and filching wallets or laptops. Most of the time, the suspect is identified as a white male, but I have never heard of or been called to vouch for a white male student of mine who was stopped "because he fit the description." But on the one occasion I can recall that the suspect was identified as a black male, a black male student of mine was stopped soon after leaving my office hours. No one offered any evidence of suspicious behavior on my student's part. He just "fit the description." The fact is that, for many white Americans, who are accustomed to distinguishing males from each other according to their height and whether they are blond, brunette, or red-headed and blue-, hazel-, or black-eyed, most black males look alike.

Ten years ago, even a high-ranking black dean at Harvard was stopped by the campus police because he "fit the description." His white student work/study assistant was called upon by the police to vouch for the dean's legitimacy. Just over a decade ago, a black law professor at Harvard was thrown up against a counter at Bloomingdale's because he was falsely accused of shoplifting. Bloomingdale's paid him $\$ 5,000$ in apology. After a few experiences like this, it takes extraordinary self-love and self-control not to either give up or explode. 
No matter how well you speak. No matter how well you dress. No matter how respectable a car you drive. No matter how many books, journal articles, and New York Times editorials you have published. No matter how right-wing they are. There is likely to come a day when your dignity and your life are worthless unless some white person-even a white person of lesser age or achievement-or an angry crowd of black people is willing to stand up and vouch for you. Otherwise, you, too, will still "fit the description." One tenured black Harvard professor tells us that throughout his career, whenever he moved to a new town-particularly with his Mercedes Benz-he has made a point of stopping by the police station with a floral arrangement and a basket of fruit to shake hands and introduce himself.

Editorialists at the Harvard Crimson newspaper, who imagine progressive academic communities otherwise, appeared to be perplexed by the black student and faculty response to the notorious events of May 12th, 2007. There, with the full authorization of all three house "masters," or residential deans, in the Quad section of campus, the Black Men's Forum and the Association of Black Harvard Women sponsored an early-afternoon picnic on the Quad lawn. A number of their non-black fellow students called the police after exchanging emails in which they expressed doubt that the picnickers were Harvard students at all. Sunglass-wearing policemen mounted on motorcycles approached and queried them. The telephone call of their fellow student to the police and the subsequent police queries suggested to the black students that they had been marked out as people who do not belong. They and I were as certain as the Crimson editorialists were doubtful that the mark they bore is racial.

And how about when it comes to the evaluation of out intellectual excellence? Let me take you back to high school-first mine and then my daughter's. A white guy who had always been slightly better than I in some classes and slightly worse in others expressed surprise that I had outscored him on the SAT's. In fact, I had received the best scores in my overwhelmingly white school. Yet I would not have been surprised if my classmate had outscored me; nor was I surprised that I had outscored him. In the years since, I have wondered what form of blindness had prompted his unilateral surprise.

Even in the ninth grade at Cambridge Rindge and Latin High School, my daughter proved a master at mock trial; among a team full of upperclassmen, she was selected as the lead prosecuting attorney. A year later, as captain, she led the team to an unprecedented series of victories. Only afterwards did we learn of the psychological battles she had had to overcome to get there. For example, early in the season, the teacher/coach had taken to lauding the team for having "Asian power!" As the match against the suburban Newton South High School approached, the teacher/coach, who happened to be Jewish, denigrated her own team's prior victories and selffulfillingly predicted failure by announcing that Newton South would not be so easy to beat because "they're Jewish boys, and they're really smart!" 
I worry here about two things. First, that teacher/coach appeared oblivious to the damage she was doing to people she cares about and wants to succeed. Second, I wonder how her prejudices are affecting her grading and her college recommendations. How often are skin color and religion causing her to assume that someone is brilliant when the person is not brilliant, and causing her to assume that someone is not brilliant when he or she is, in fact, brilliant?

One expects one's fellow university scholars to have acquired a self-consciousness of perception and inference that would prevent their leaping to the wrong conclusions about fellow scholars of other colors and genders. But the impulse of stereotyping can lock down reasoning in the progressive academy as well. For example, consider the story of M.I.T. alum and now Stanford University neurobiologist Ben Barres, who is now a man but was, before 1997, a woman. He tells the story of having presented his work to a group of scientists, some of whom had also heard him present when he was a woman. Ben Barres reports overhearing one scientist, who was unaware of his sex change, say, "Ben Barres gave a great seminar today, but then his work is much better than his sister's." Even smart, good-willed scientists are affected by their prejudices about the differential capabilities of people with different skin colors and sexes.

At Harvard, most black professors have a good rapport with their white colleagues. But we must never forget that smart, competitive people also have intellectually powerful means of rationalizing their assumptions, justifying the undue privileges they have received, and finding ways of legitimizing the exclusion of the people who have not gained the same privileges. The Larry Summers Affair provides an enormous array of examples. Before Lawrence Summers' hubristic attack on Cornell West, Professor West was the most popular teacher on campus and one of the most widely published professors. Having been awarded tenure by both Princeton and Harvard, he had also achieved such distinction that Summers' predecessor, Neil Rudenstine, had named West a University Professor, the highest rank of professor in the University. Moreover, he was widely loved and admired by his colleagues of all hues. Once Lawrence Summers decided to beat up on him-reportedly while complaining that West was more famous than he-many of those same colleagues (along with much of the white public) suddenly began whispering that, where there was smoke, there must be fire. After all, didn't Cornell West "fit the description"? Maybe he wasn't really as brilliant as everybody had been saying.

These same people repeated nother evidence-free litany about Mr. "The-Economic-Logic-of-Dumping-Toxic-Waste-inthe-Lowest-Wage-Country-Is-Impeccable." Former University president Lawrence Summers had signed a memo containing this phrase while he served as Chief Economic Officer at the World Bank. ${ }^{2}$ His defenders continued to incant the article of faith that Summers - a white man at Harvard with two Nobel laureate uncles-was "brilliant." Most of them offered up the same litany when Summers declared the critics of 
Israel's American-funded land-stealing and military brutality "anti-Semitic in effect if not intent," comparing these critics to people who assault innocent Jews in Europe and knock over Jewish headstones. Few were willing to declare the comparison what it is-intellectually sloppy and self-serving.

Perhaps the most sanctimonious and unquestioned genre of racism on Harvard's campus is the premise that Jewish people have a racially inherited right to the land of Palestine, which, on account of the Holocaust, supersedes the property and residency rights of the 700,000 to 800,000 Palestinian natives who, in 1948, were forced from that land. On U.S. college campuses, some of the most ardent opponents of domestic racism and of anti-Semitism in Europe seem oblivious to the double standard that denies Palestinians the right of return, solely on account of their ancestry, and confers the right of return upon others, after millennia of absence, solely based upon their ancestry. Jewish property expropriated in Europe is rightly returned, while Palestinian property is, without apology, bulldozed and turned into settlements for newly-arrived immigrants. On some U.S. college campuses, to question this double standard is to invite the most caustic name-calling and character assassination. ${ }^{3}$

It took some powerful rationalizing to keep calling Summers "brilliant" after each of his muscular, anti-intellectual displays, which, of course, included a speech to a conference on Native Americans about the relative blamelessness of EuroAmericans for the decimation and displacement of Native
Americans, as well as his world-famous expression of doubt about women's scientific competency and his quick dismissal of reports of discrimination against them in the natural sciences. Because university scholars are usually thoughtful and slow to speak out, it is difficult to tell whether the four years of relative silence over Summers' anti-intellectual assaults on historically oppressed peoples-not to mention Harvey Mansfield's "brilliant" but disproven inference that black students are to blame for grade inflation and Alan Dershowitz's various "brilliantly" untruthful tirades against Israel's critics-resulted from self-interest, flawed reasoning, or the ethic that he who debates a fool is a fool.

In sum, I am making three points about educated, progressive Americans' thinking about hereditary social groups. First, some individuals, on account of the racial, hereditary religious, and gender groups to which they belong, receive far too great a benefit of the doubt when it comes to discussions of their intelligence. Second, even brilliant professors often stand by in silence as they hear the competency and rights of other groups of people questioned. Until one's own group is on the receiving end of this slander, most of us are willing to shut up and rationalize that our momentary exemption from attack means that we really deserve the sometimes-fragile privileges we have secured. Finally, it should be said that there are bullies in the academy-petty little war chiefs who like to throw their weight around. And, in my experience, they are quicker to throw it up against someone who "fits the description" than against a colleague who is armored in whiteness and maleness.

2. J. Lorand Matory, "Why I Stood Up: the Case against Summers," The Harvard Crimson, 7 June 2006; J. Lorand Matory, "Israel and Censorship at Harvard," The Harvard Crimson, 14 September 2007; J. Lorand Matory, "Orwellian Uses of 'Free Speech," The Harvard Crimson, 30 November 2007.

3. J. Lorand Matory, "What Do Critics of Israel Have to Fear?” The Harvard Crimson, 5 June 2008. 
Racism affects the pipeline of students entering the university and entering the professoriate. Not all children and young adults learn from the words and behavior of their teachers that their intelligence is normal and right, that their original perspectives are important enough to be heard by the world, that they deserve-and will receive-a warm welcome in their professors' office hours. Nor do they learn from police that their rights are equally respected and their efforts to obey the law equally valuable. Racism forces black faculty, staff, and students, in particular, to wonder whether our intellectual interests and family lives matter to the administration, but not only that.

We also have to worry about our physical safety on campus. We have to worry about what we wear, where we go, and how we speak more than members of the white majority do, and we also have to worry about whether our careful self-presentation will make any difference whatsoever. We wonder-with full justification-whether we will be judged fairly, and whether, in the midst of a conflict with our inevitable rivals and detractors, we will receive the same benefit of the doubt as those who do not "fit the description." Will even our black colleagues feel safe enough to stand up for what they know is the truth? Some part of the solution to these worries is concrete and obvious. Universities need more black faculty, staff and students, so that the $13 \%$ of the American population that is black can become less of a supercharged symbol in somebody else's fantasy life, and more a range of human beings with diverse talents and ways of making the world a better place.
The other concrete need is for the entire university community to recognize that the world is not color-blind, and that a careful, self-conscious, and hyper-cautious level of procedural circumspection is sometimes necessary in order to guarantee fairness to those who "fit the description." 


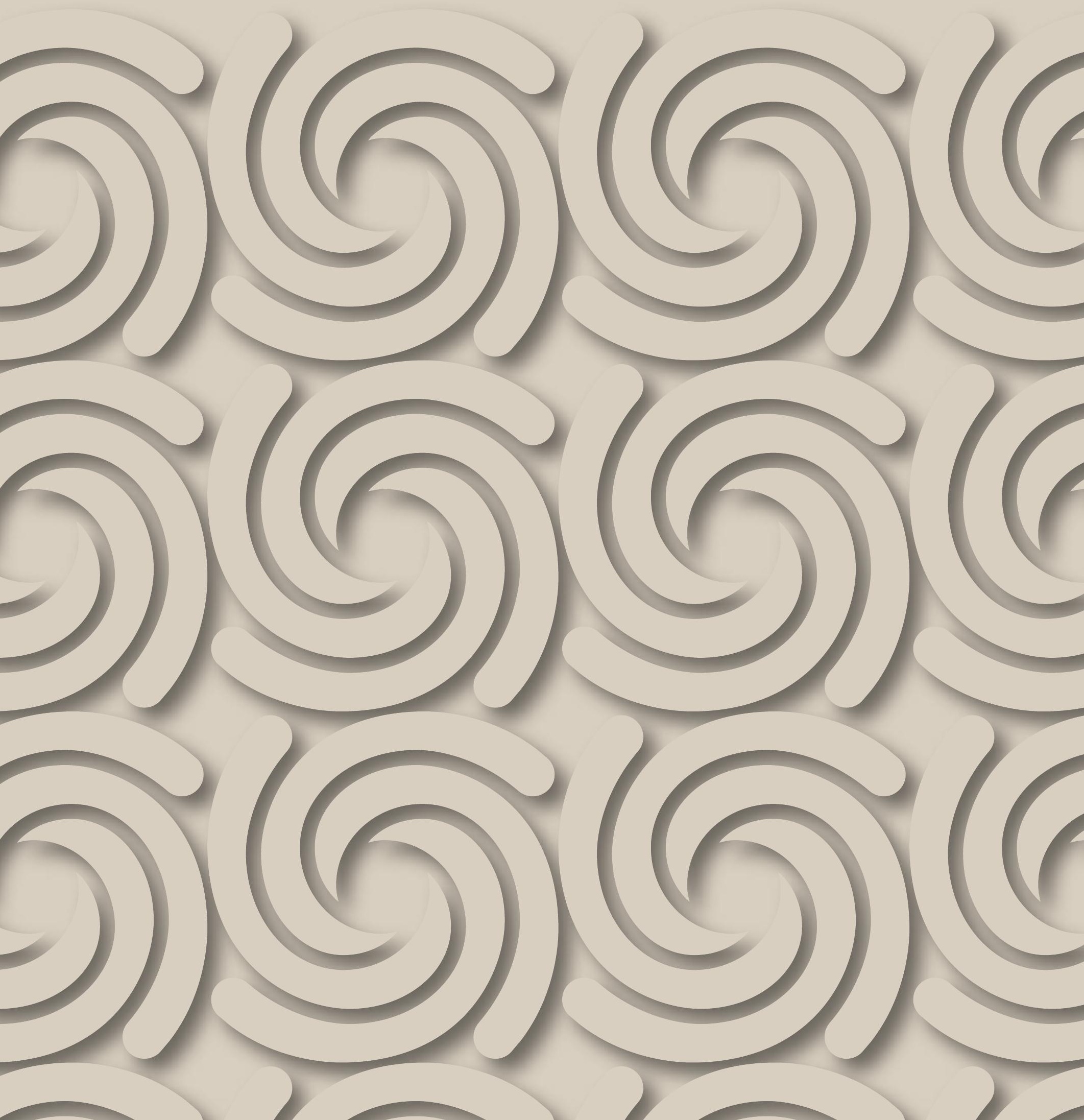

